\title{
Long Term Monitoring in Switzerland Reveals That Adalia bipunctata Strongly Declines in Response to Harmonia axyridis Invasion
}

\author{
Marc Kenis ${ }^{1, *}$, Saidou Nacambo ${ }^{1}$, Johan Van Vlaenderen ${ }^{1}$, Renate Zindel ${ }^{1,2}$ and René Eschen ${ }^{1}$ \\ 1 CABI, 1 Rue des Grillons, 2800 Delémont, Switzerland; s.nacambo@cabi.org (S.N.); \\ j.vanvlaenderen@gmail.com (J.V.V.); renatezindel@gmail.com (R.Z.); r.eschen@cabi.org (R.E.) \\ 2 Department of Biology, University of Fribourg, 1700 Fribourg, Switzerland \\ * Correspondence: m.kenis@cabi.org; Tel.: +41-324-214-884
}

Received: 15 November 2020; Accepted: 11 December 2020; Published: 12 December 2020

check for updates

Simple Summary: The harlequin ladybird, Harmonia axyridis, is an Asian species that has invaded Europe and other continents, where it is suspected to cause the decline of native ladybirds through competition and predation. In north-western Switzerland, ladybirds were monitored for 11 years in four habitats (broadleaved hedges, meadows, pine and spruce stands) to assess the decline of native ladybirds following the invasion of the harlequin ladybird. These surveys showed that, on broadleaved hedges, the harlequin ladybird quickly became the most abundant species, representing $60-80 \%$ of all specimens collected in this habitat. One species, the two-spot ladybird, Adalia bipunctata, almost disappeared during this period, whereas it was the most abundant ladybird on broadleaved trees and shrubs when this study started. The other native species did not show any clear sign of decline. The harlequin ladybird was the second most abundant species in pine stands, and was not abundant in meadows and in spruce stands. The total number of ladybirds feeding on aphids did not decline during this period, suggesting that the arrival of the harlequin ladybird did not affect the predation pressure on aphids. Nevertheless, the severe decline of the two-spot ladybird deserves further investigations.

\begin{abstract}
A long-term monitoring was conducted at 40 sites in four different habitats in north-western Switzerland to observe changes in populations of native ladybirds, following the invasion of the Asian harlequin ladybird, Harmonia axyridis. From 2006 to 2017, the same trees and meadows were sampled at least seven times per year using standard protocols. On 15 broadleaved hedges, $H$. axyridis quickly became the dominant species, representing 60 to $80 \%$ of adult ladybirds collected. It was second in abundance at five pine (Pinus sylvestris) stands and was a minor component of the ladybird complex at five spruce (Picea abies) stands and in 15 meadows. This survey revealed the severe decline of Adalia bipunctata, which was the most abundant native ladybird on broadleaved trees in 2006-2009 and has almost disappeared since 2010. So far, other native ladybirds do not seem to decline significantly, including species occupying the same ecological niches as H. axyridis. The total number of aphidophagous ladybirds did not decline either, suggesting that the biological control function of ladybirds on aphids living in these habitats has not been affected by the arrival of $H$. axyridis. Recommendations are given to further assess the impact of $H$. axyridis on native ladybirds and aphids.
\end{abstract}

Keywords: Adalia bipunctata; Coccinellidae; Harmonia axyridis; invasive species; ladybirds

\section{Introduction}

The harlequin ladybird, Harmonia axyridis (Pallas) (Coleoptera: Coccinellidae), is a polyphagous predator native to Central and East Asia, which has been used as a biological control agent against 
aphids in North America and Europe, in greenhouses as well as in outdoor crops. In North America, it has been considered established in the wild since 1988, and very quickly became the dominant ladybird in many ecosystems [1]. In Europe, it has been tested since 1982, and was first marketed in 1995 [2]. Since populations were first observed in the wild in 1999 in Germany, its abundance has increased exponentially, and the species is now established in almost all European countries [3]. In Switzerland, a first individual was found in Basel in 2004 and the establishment of the species was confirmed in 2006 [4]. It is now found throughout the country except in high elevation areas [5].

The invasion of $H$. axyridis has a number of negative effects [3]. It is a human nuisance when it aggregates in buildings in autumn and can taint wine when harvested and crushed with grapes. However, most concern so far has been caused by its impact on biodiversity. Due to its predatory and competitive abilities, $H$. axyridis may affect many native species, including non-pest aphids and aphidophagous insects. In particular, native ladybirds may suffer from competition for resources and intra-guild predation (IGP) on larvae and eggs ([3] and references therein). In North America, several studies showed that $H$. axyridis has displaced native ladybirds [6-8]. Similar observations were made in Chile, where it is also invasive [9]. In Europe, first analyses made a few years after the establishment of H. axyridis in UK, Belgium and Switzerland suggested that several native ladybird species had started declining $[10,11]$. In a risk assessment based on the likelihood that the assessed native species encounters $H$. axyridis in the field, the hazard of competition for food, and the IGP hazard, Kenis et al. [12] stated that four European species were particularly at risk, i.e., Adalia bipunctata (L.), Adalia decempunctata (L.), Oenopia conglobata (L.) and Calvia decemguttata (L.). These are species that, as $H$. axyridis, are found mainly on deciduous trees, are primarily aphidophagous and have immature stages which are highly vulnerable to IGP by $H$. axyridis. These studies and others emphasized the need for further field assessments of native ladybirds' decline in Europe but, since ladybird populations are known to naturally fluctuate from year to year $[13,14]$, it is essential that such assessments are based on long-term studies. Brown and Roy [15] provided population changes at four sites in England over an 11-year period (2006-2016) following invasion by H. axyridis. Their survey focused on three plants: lime trees (Tilia x europea), pine (Pinus sylvestris) and nettle (Urtica dioica). While H. axyridis was over three times more abundant than the second commonest species, it only dominated at the lime sites and only one native species, A. bipunctata, significantly declined.

Here, we present the results of another long-term survey conducted at 40 sites in Switzerland in the period 2006-2017, to observe changes in populations of native ladybirds before, during and after the arrival of $H$. axyridis and assess their potential decline.

\section{Materials and Methods}

A long-term field trial was set up in north-western Switzerland in the cantons Jura, Basel-Landschaft, Basel-Stadt and Aargau, based on 40 permanent sites established within a $40 \mathrm{~km}$ distance from the town of Delémont (Table S1 in Supplementary file). Thirty sites were selected in 2006: 15 "meadow sites" consisting of managed and unmanaged meadows, along roads, sampled by sweeping 60 times through the vegetation on a transect of $30 \mathrm{~m}$ with a $60 \mathrm{~cm}$-diameter sweep net; 15 "broadleaved hedges" consisting of clearly delimited, ca. $50 \mathrm{~m}$ long planted hedgerows, semi-natural hedges or forest hedges of mixed broadleaved trees and shrubs, sampled by beating all branches up to a height of $2.5 \mathrm{~m}$ with a stick and collecting beetles falling down on a white, rectangular $90 \times 125 \mathrm{~cm}$ beating tray. In 2007, 10 "conifer sites" were selected, all in the Jura, except one in Basel-Landschaft. They consisted of 4 to 10 preselected individual pine (Pinus sylvestris, 5 sites), and spruce (Picea Abies, 5 sites) trees, of which all branches up to $2.5 \mathrm{~m}$ were beaten above the same beating tray. All sites were chosen haphazardly. The same sites were sampled seven to ten times per year per site, from mid-April to late September from 2006 (2007 for the conifers) until 2013. No sampling was conducted in 2014 because of budget constraints. In the period 2015-2017, similar collections were made at the same sites, except that one site of broadleaved hedges had disappeared and was replaced by another in the same region. Five meadow sites were also replaced by other, very similar meadows. 
Adult ladybirds were identified to species on-site using various identification keys [16-18] and all ladybirds (adults and larvae) were replaced on the branches or in the meadow after identification. Only "true" ladybirds, i.e., those belonging to the sub-families Coccinellinae, Chilocorinae and Epilachninae were included in the study, because they are easier to identify in the field than the small Coccidulinae and Scymninae [18]. The amount of aphidophagous ladybird adults obtained per collection on broadleaved hedges was assessed, and the ladybird species were classified as mainly aphidophagous, based on Kenis et al. [12].

\section{Results}

A total of 10,248 adults belonging to 25 species were collected during this study. Figures 1-4 show the proportion of $H$. axyridis in the four habitats since the start of sampling in 2006 and 2007 and Tables 1-4 give details of the species collected.

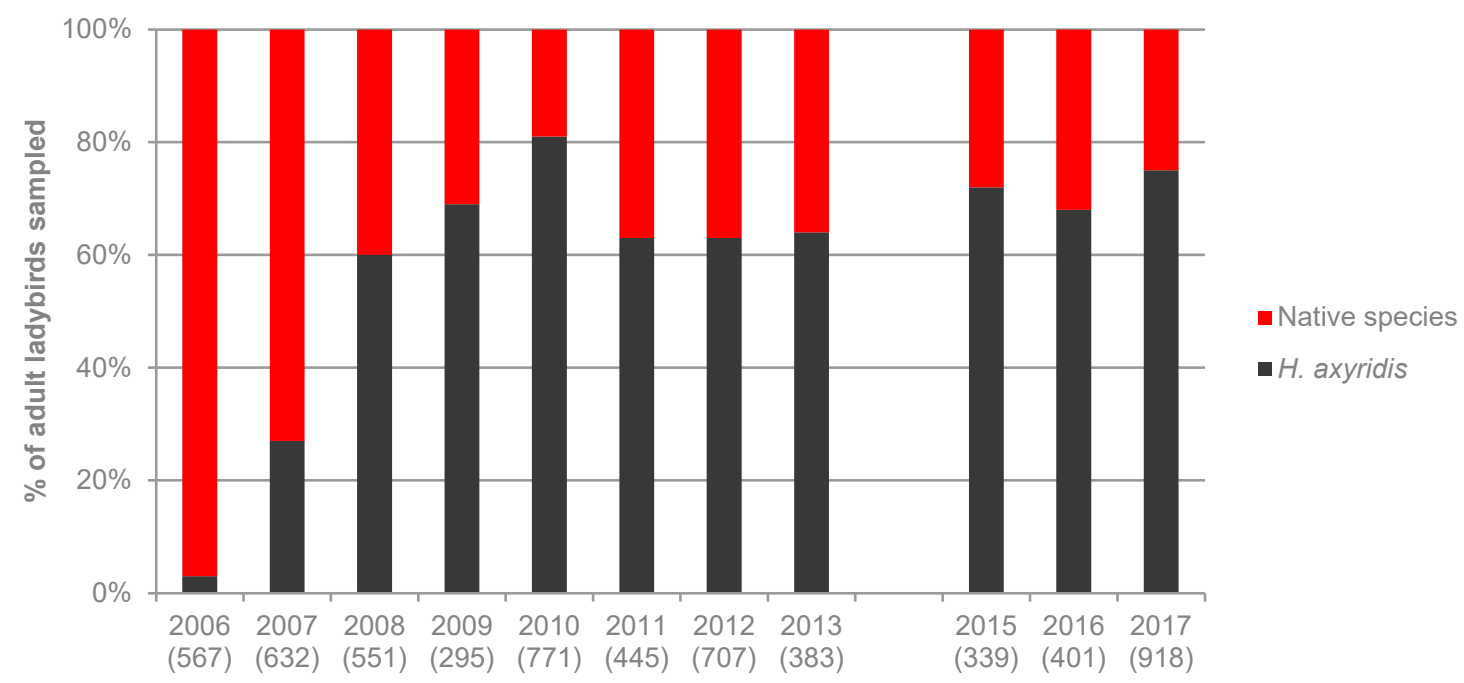

Figure 1. Percentage of Harmonia axyridis and native species at the 15 broadleaved hedges from 2006 to 2017. Numbers between parentheses indicate the number of adult ladybirds collected.

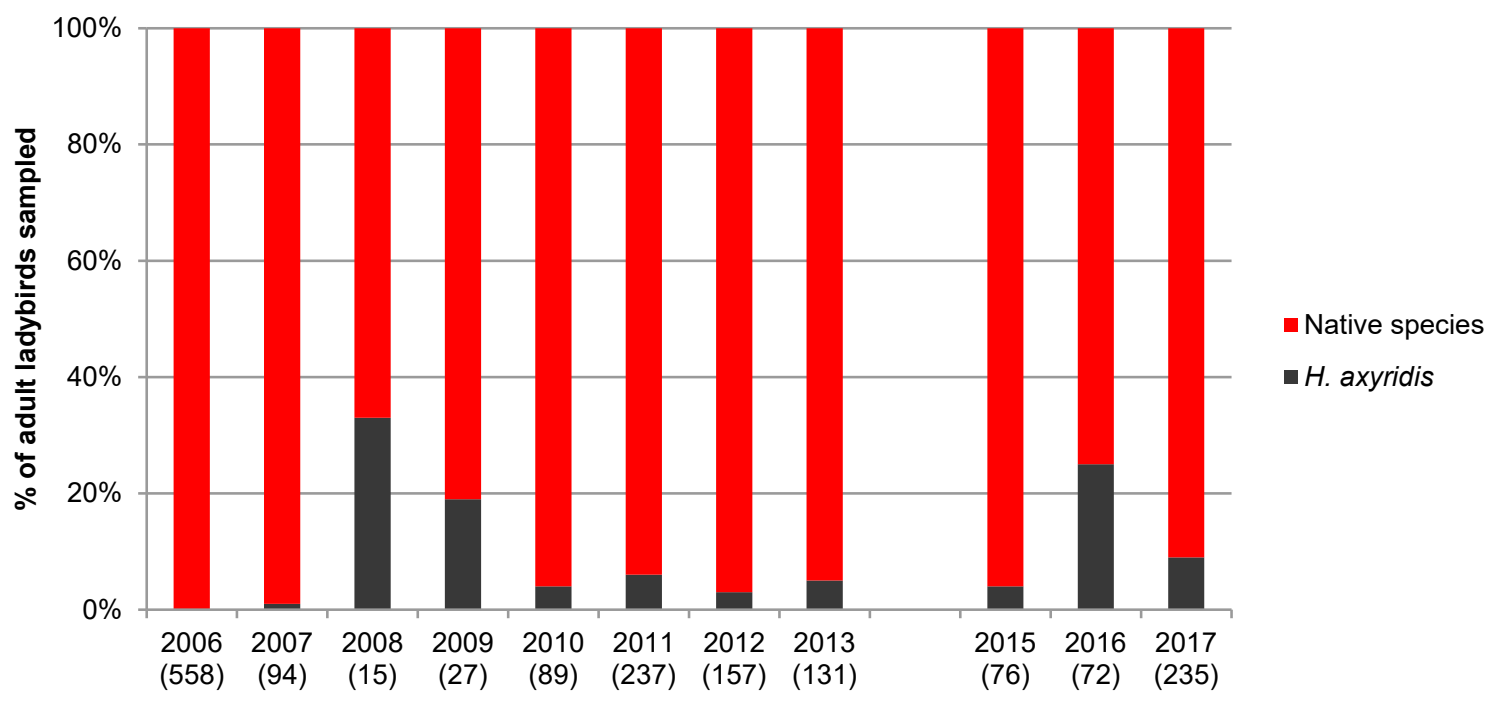

Figure 2. Percentage of Harmonia axyridis and native species in the 15 meadows from 2006 to 2017. Numbers between parentheses indicate the number of adult ladybirds collected. 


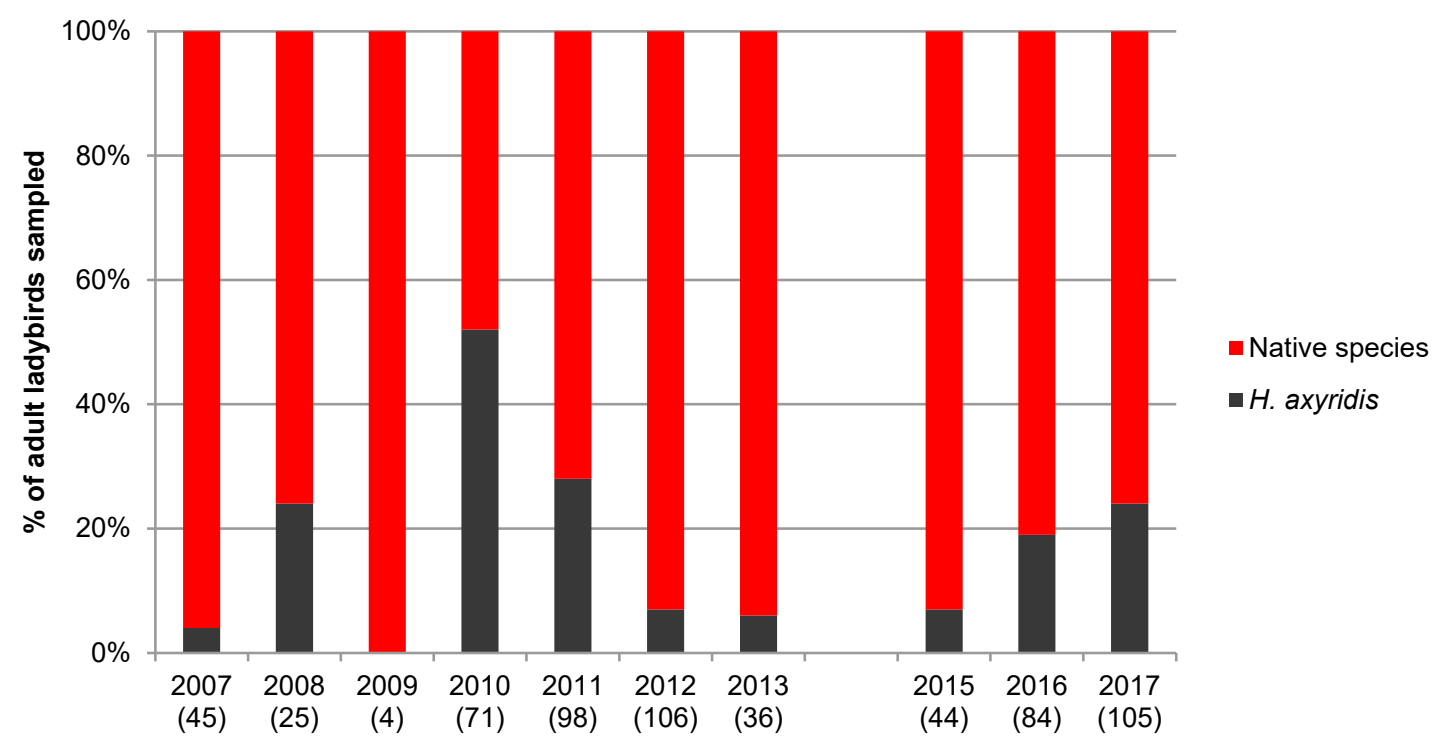

Figure 3. Percentage of Harmonia axyridis and native species at the five pine sites from 2007 to 2017. Numbers between parentheses indicate the number of adult ladybirds collected.

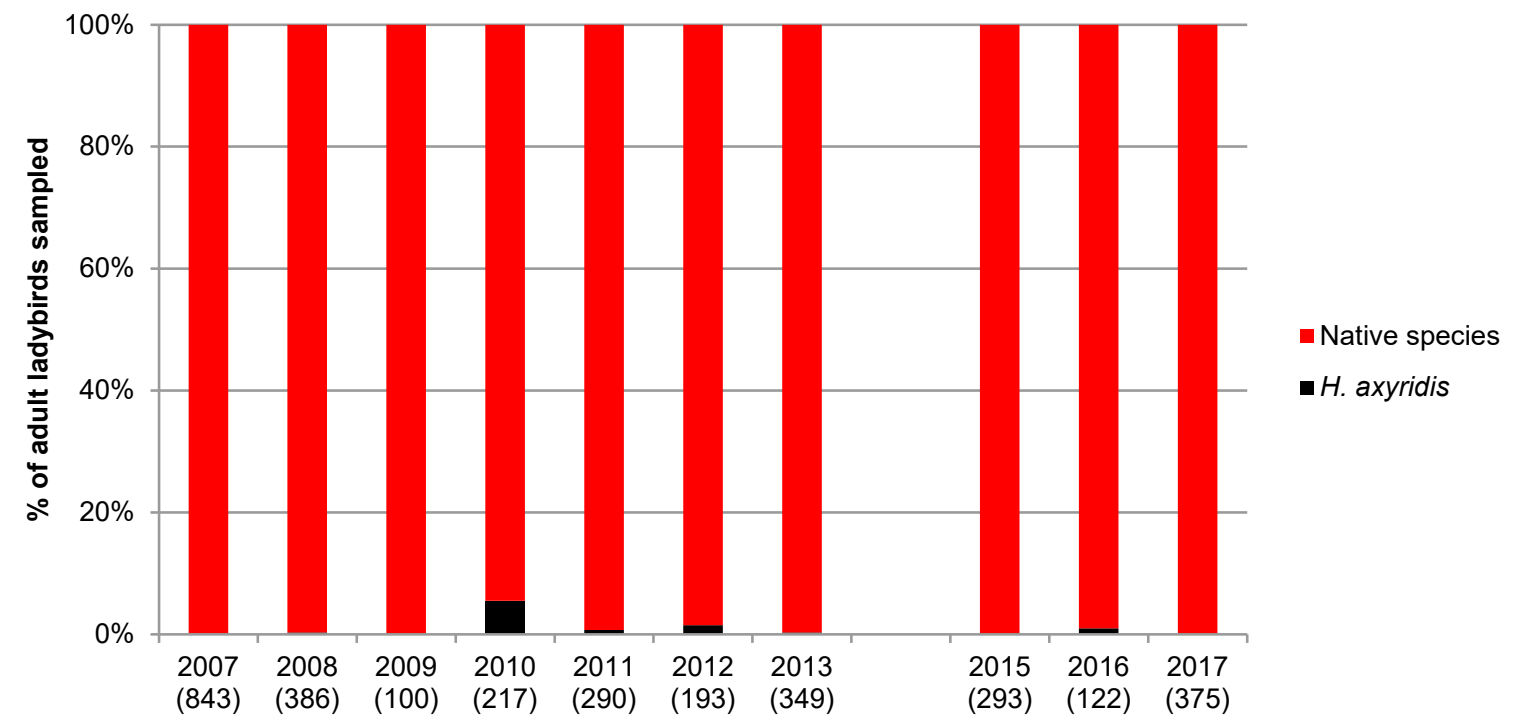

Figure 4. Percentage of Harmonia axyridis and native species at the five spruce sites from 2007 to 2017. Numbers between parenthesis indicate the number of adult ladybirds collected. 
Table 1. Species and number of adult ladybirds collected at the 15 broadleaved hedges from 2006 to 2017 . Numbers between parentheses indicate the number of collections. Ladybirds were not sampled in 2014.

\begin{tabular}{|c|c|c|c|c|c|c|c|c|c|c|c|c|}
\hline & $\begin{array}{c}2006 \\
(9-10)\end{array}$ & $\begin{array}{l}2007 \\
(8-9)\end{array}$ & $\begin{array}{c}2008 \\
(9)\end{array}$ & $\begin{array}{c}2009 \\
(9)\end{array}$ & $\begin{array}{c}2010 \\
(7)\end{array}$ & $\begin{array}{c}2011 \\
(7)\end{array}$ & $\begin{array}{c}2012 \\
(7)\end{array}$ & $\begin{array}{c}2013 \\
(7)\end{array}$ & $\begin{array}{c}2015 \\
(7)\end{array}$ & $\begin{array}{c}2016 \\
(7)\end{array}$ & $\begin{array}{c}2017 \\
(7)\end{array}$ & Total \\
\hline Adalia bipunctata (L.) & 46 & 150 & 57 & 39 & 1 & 1 & 1 & 1 & 0 & 1 & 0 & 297 \\
\hline Adalia decempunctata (L.) & 92 & 67 & 94 & 24 & 79 & 18 & 91 & 41 & 21 & 52 & 93 & 672 \\
\hline Anatis ocellata (L.) & 1 & 1 & 0 & 0 & 0 & 0 & 1 & 0 & 0 & 0 & 0 & 3 \\
\hline Aphidecta obliterata (L.) & 0 & 0 & 0 & 0 & 0 & 0 & 0 & 1 & 0 & 0 & 0 & 1 \\
\hline Calvia quatuordecimguttata (L.) & 31 & 60 & 21 & 5 & 21 & 20 & 21 & 17 & 17 & 22 & 39 & 274 \\
\hline Calvia decemguttata (L.) & 0 & 0 & 1 & 1 & 1 & 0 & 1 & 0 & 4 & 0 & 7 & 15 \\
\hline Chilocorus bipustulatus (L.) & 0 & 42 & 2 & 0 & 1 & 1 & 0 & 0 & 0 & 0 & 3 & 49 \\
\hline Chilocorus renipustulatus (Scriba) & 0 & 36 & 0 & 0 & 0 & 0 & 0 & 0 & 0 & 0 & 1 & 37 \\
\hline Coccinella quinquepunctata L. & 1 & 0 & 0 & 0 & 0 & 0 & 0 & 0 & 0 & 0 & 0 & 1 \\
\hline Coccinella septempunctata $\mathrm{L}$ & 23 & 10 & 1 & 2 & 7 & 46 & 46 & 7 & 15 & 1 & 1 & 159 \\
\hline Exochomus quadripustulatus (L.) & 37 & 41 & 2 & 1 & 2 & 24 & 27 & 9 & 6 & 12 & 17 & 178 \\
\hline Halizia sedecimguttata (L.) & 23 & 1 & 7 & 3 & 1 & 10 & 1 & 0 & 3 & 2 & 32 & 83 \\
\hline Harmonia axyridis (Pallas) & 13 & 168 & 332 & 205 & 622 & 281 & 444 & 245 & 243 & 273 & 689 & 3515 \\
\hline Harmonia quadripunctata Pontoppidan & 2 & 2 & 2 & 0 & 0 & 1 & 0 & 0 & 0 & 0 & 0 & 7 \\
\hline Henosepilachna argus (Geoffroy) & 0 & 0 & 0 & 0 & 0 & 0 & 1 & 1 & 1 & 0 & 0 & 3 \\
\hline Hippodamia variegata (Goeze) & 2 & 1 & 0 & 0 & 0 & 0 & 0 & 0 & 0 & 0 & 1 & 4 \\
\hline Myzia oblonguttata (L.) & 0 & 0 & 0 & 0 & 0 & 0 & 0 & 0 & 1 & 0 & 0 & 1 \\
\hline Oenopia conglobata (L.) & 2 & 13 & 5 & 1 & 3 & 3 & 10 & 4 & 2 & 2 & 7 & 52 \\
\hline Platynaspis luteorubra (Goeze) ${ }^{*}$ & 14 & 2 & 1 & 0 & 0 & 0 & 5 & 2 & 0 & 0 & 0 & 24 \\
\hline Propylea quatuordecimpunctata (L.) & 170 & 26 & 17 & 12 & 26 & 38 & 51 & 44 & 24 & 14 & 21 & 443 \\
\hline Psyllobora vigintiduopunctata (L.) & 9 & 11 & 1 & 2 & 6 & 2 & 7 & 11 & 2 & 22 & 3 & 76 \\
\hline Subcoccinella vigintiquatuorpunctata (L.) & 1 & 1 & 8 & 0 & 1 & 0 & 0 & 0 & 0 & 0 & 4 & 15 \\
\hline Total & 467 & 632 & 551 & 295 & 771 & 445 & 707 & 383 & 339 & 401 & 918 & 4991 \\
\hline
\end{tabular}

* In the field, Platynaspis luteorubra can be confused with Scymninae, a sub-family not covered in this study. Therefore, it cannot be ruled out that some specimens have been misidentified. 
Table 2. Species and number of adult ladybirds collected in the 15 meadows from 2006 to 2017. Numbers between parentheses indicate the number of collections. Ladybirds were not sampled in 2014.

\begin{tabular}{|c|c|c|c|c|c|c|c|c|c|c|c|c|}
\hline & $\begin{array}{c}2006 \\
(9)\end{array}$ & $\begin{array}{l}2007 \\
(8-9)\end{array}$ & $\begin{array}{c}2008 \\
(9)\end{array}$ & $\begin{array}{c}2009 \\
(9)\end{array}$ & $\begin{array}{c}2010 \\
(7)\end{array}$ & $\begin{array}{c}2011 \\
(7)\end{array}$ & $\begin{array}{c}2012 \\
(7)\end{array}$ & $\begin{array}{c}2013 \\
(7)\end{array}$ & $\begin{array}{c}2015 \\
(7)\end{array}$ & $\begin{array}{c}2016 \\
(7)\end{array}$ & $\begin{array}{c}2017 \\
(7)\end{array}$ & Total \\
\hline Adalia bipunctata & 0 & 4 & 2 & 6 & 0 & 0 & 0 & 0 & 0 & 0 & 0 & 12 \\
\hline Adalia decempunctata & 1 & 0 & 1 & 3 & 0 & 2 & 0 & 0 & 0 & 4 & 4 & 15 \\
\hline Anatis ocellata & 1 & 0 & 0 & 0 & 0 & 0 & 0 & 0 & 0 & 0 & 0 & 1 \\
\hline Calvia quatuordecimguttata & 0 & 1 & 0 & 0 & 1 & 0 & 0 & 0 & 0 & 1 & 3 & 6 \\
\hline Chilocorus renipustulatus & 0 & 1 & 0 & 0 & 0 & 0 & 0 & 0 & 0 & 0 & 0 & 1 \\
\hline Coccinella quiquepunctata & 0 & 0 & 0 & 1 & 1 & 0 & 0 & 0 & 0 & 0 & 0 & 2 \\
\hline Coccinella septempunctata & 36 & 10 & 1 & 3 & 8 & 52 & 34 & 8 & 28 & 0 & 3 & 183 \\
\hline Coccinula quatuordecimpunctata (L.) & 0 & 0 & 0 & 0 & 0 & 0 & 1 & 0 & 0 & 0 & 0 & 1 \\
\hline Exochomus quadripustulatus & 0 & 1 & 0 & 0 & 0 & 0 & 1 & 1 & 0 & 0 & 3 & 6 \\
\hline Halizia sedecimguttata & 0 & 0 & 0 & 0 & 0 & 0 & 0 & 0 & 0 & 1 & 1 & 2 \\
\hline Harmonia axyridis & 0 & 1 & 5 & 5 & 4 & 15 & 4 & 7 & 3 & 18 & 20 & 82 \\
\hline Hippodamia variegata & 10 & 20 & 2 & 0 & 21 & 33 & 7 & 16 & 3 & 3 & 28 & 143 \\
\hline Platynaspis luteorubra* & 5 & 0 & 1 & 0 & 0 & 0 & 2 & 10 & 0 & 1 & 0 & 19 \\
\hline Propylea quatuordecimpunctata & 103 & 18 & 1 & 5 & 19 & 42 & 60 & 39 & 21 & 23 & 56 & 387 \\
\hline Psyllobora vigintiduopunctata & 26 & 12 & 0 & 0 & 3 & 16 & 12 & 13 & 6 & 6 & 36 & 130 \\
\hline Subcoccinella vigintiquatuoropunctata & 29 & 8 & 1 & 4 & 7 & 18 & 8 & 2 & 0 & 3 & 20 & 100 \\
\hline Tytthaspis sedecimpunctata (L.) & 348 & 18 & 1 & 0 & 25 & 59 & 28 & 42 & 15 & 12 & 61 & 609 \\
\hline Total & 559 & 94 & 15 & 27 & 89 & 237 & 157 & 138 & 76 & 72 & 235 & 1464 \\
\hline
\end{tabular}

* In the field, Platynaspis luteorubra can be confused with Scymninae, a sub-family not covered in this study. Therefore, it cannot be ruled out that some specimens have been misidentified. 
Table 3. Species and number of adult ladybirds collected at the five pine sites from 2007 to 2017. Numbers between parentheses indicate the number of collections. Ladybirds were not sampled in 2014.

\begin{tabular}{|c|c|c|c|c|c|c|c|c|c|c|c|}
\hline & $\begin{array}{c}2007 \\
(7)\end{array}$ & $\begin{array}{c}2008 \\
(8)\end{array}$ & $\begin{array}{c}2009 \\
(7)\end{array}$ & $\begin{array}{c}2010 \\
(7)\end{array}$ & $\begin{array}{c}2011 \\
(7)\end{array}$ & $\begin{array}{c}2012 \\
(7)\end{array}$ & $\begin{array}{c}2013 \\
(7)\end{array}$ & $\begin{array}{c}2015 \\
(7)\end{array}$ & $\begin{array}{c}2016 \\
(7)\end{array}$ & $\begin{array}{c}2017 \\
(7)\end{array}$ & Total \\
\hline Adalia bipunctata & 1 & 0 & 2 & 0 & 0 & 0 & 0 & 0 & 0 & 0 & 3 \\
\hline Adalia decempunctata & 2 & 2 & 1 & 0 & 0 & 2 & 2 & 0 & 4 & 11 & 24 \\
\hline Anatis ocellata & 2 & 0 & 0 & 1 & 0 & 16 & 4 & 3 & 2 & 0 & 28 \\
\hline Aphidecta obliterata & 1 & 4 & 0 & 2 & 0 & 3 & 0 & 0 & 10 & 0 & 20 \\
\hline Chilocorus bipustulatus & 0 & 0 & 0 & 0 & 0 & 0 & 0 & 2 & 0 & 2 & 4 \\
\hline Chilocorus renipustulatus & 0 & 0 & 0 & 0 & 0 & 0 & 0 & 0 & 0 & 1 & 1 \\
\hline Coccinella quinquepunctata & 1 & 0 & 0 & 0 & 0 & 0 & 0 & 1 & 0 & 0 & 2 \\
\hline Coccinella septempunctata & 5 & 0 & 0 & 18 & 39 & 15 & 4 & 5 & 1 & 15 & 102 \\
\hline Exochomus quadripustulatus & 17 & 5 & 0 & 1 & 3 & 6 & 6 & 6 & 6 & 7 & 57 \\
\hline Halizia sedecimguttata & 0 & 0 & 0 & 0 & 0 & 2 & 0 & 0 & 0 & 0 & 2 \\
\hline Harmonia axyridis & 2 & 6 & 0 & 37 & 27 & 8 & 2 & 3 & 16 & 25 & 126 \\
\hline Harmonia quadripunctata & 9 & 7 & 1 & 8 & 25 & 41 & 4 & 15 & 29 & 25 & 164 \\
\hline Myrrha octodecimguttata (L.) & 0 & 0 & 0 & 0 & 0 & 3 & 0 & 0 & 6 & 0 & 9 \\
\hline Myzia oblonguttata & 5 & 1 & 0 & 4 & 4 & 16 & 9 & 9 & 9 & 19 & 76 \\
\hline Platynaspis luteorubra* & 0 & 0 & 0 & 0 & 0 & 0 & 2 & 0 & 0 & 0 & 2 \\
\hline Propylea quatuordecimpunctata & 0 & 0 & 0 & 0 & 0 & 2 & 3 & 0 & 1 & 0 & 6 \\
\hline Total & 45 & 25 & 4 & 71 & 98 & 114 & 36 & 44 & 84 & 105 & 623 \\
\hline
\end{tabular}

* In the field, Platynaspis luteorubra can be confused with Scymninae, a sub-family not covered in this study. Therefore, it cannot be ruled out that some specimens have been misidentified. 
Table 4. Species and number of adult ladybirds collected at the five spruce sites from 2007 to 2017. Numbers between parentheses indicate the number of collections. Ladybirds were not sampled in 2014

\begin{tabular}{|c|c|c|c|c|c|c|c|c|c|c|c|}
\hline & $\begin{array}{c}2007 \\
(7)\end{array}$ & $\begin{array}{c}2008 \\
(8)\end{array}$ & $\begin{array}{c}2009 \\
(7)\end{array}$ & $\begin{array}{c}2010 \\
(7)\end{array}$ & $\begin{array}{c}2011 \\
(7)\end{array}$ & $\begin{array}{c}2012 \\
(7)\end{array}$ & $\begin{array}{c}2013 \\
(7)\end{array}$ & $\begin{array}{c}2015 \\
(7)\end{array}$ & $\begin{array}{c}2016 \\
(7)\end{array}$ & $\begin{array}{c}2017 \\
(7)\end{array}$ & Total \\
\hline Adalia bipunctata & 4 & 0 & 0 & 0 & 0 & 0 & 0 & 0 & 0 & 0 & 4 \\
\hline Adalia decempunctata & 74 & 4 & 0 & 6 & 0 & 0 & 0 & 2 & 0 & 1 & 87 \\
\hline Aphidecta obliterata & 671 & 366 & 99 & 126 & 123 & 137 & 254 & 237 & 121 & 284 & 2417 \\
\hline Calvia quatuordecimguttata & 2 & 0 & 0 & 0 & 0 & 0 & 0 & 0 & 0 & 0 & 2 \\
\hline Calvia decemguttata & 0 & 0 & 0 & 0 & 0 & 0 & 1 & 0 & 0 & 0 & 1 \\
\hline Exochomus quadripustulatus & 0 & 0 & 0 & 3 & 0 & 1 & 2 & 1 & 0 & 4 & 11 \\
\hline Halizia sedecimguttata & 2 & 0 & 0 & 1 & 0 & 1 & 0 & 0 & 0 & 0 & 4 \\
\hline Harmonia axyridis & 1 & 1 & $\mathbf{0}$ & 12 & 2 & 3 & 1 & $\mathbf{0}$ & 1 & $\mathbf{0}$ & 21 \\
\hline Harmonia quadripunctata & 0 & 0 & 0 & 0 & 0 & 1 & 0 & 0 & 0 & 0 & 1 \\
\hline Myzia oblonguttata & 19 & 4 & 0 & 2 & 0 & 1 & 1 & 1 & 0 & 0 & 28 \\
\hline Platynaspis luteorubra* & 0 & 0 & 0 & 0 & 0 & 0 & 1 & 0 & 0 & 0 & 1 \\
\hline
\end{tabular}

* In the field, Platynaspis luteorubra can be confused with Scymninae, a sub-family not covered in this study. Therefore, it cannot be ruled out that some specimens have been misidentified. 
On broadleaved hedges, $H$. axyridis was present in low numbers in 2006, at two of the 15 sites. In 2007, it already represented 27\% of all ladybird beetles and from 2008 to 2017, its proportion varied between 60 and $80 \%$ (Figure 1). A total of 21 native species were collected on the hedges (Table 1). Although the number of specimens collected per species varied between years, only one species, A. bipunctata, clearly declined during this period (Table 1, Figure 5). It was the main native species from 2006 to 2009 and, since 2010, not more than one specimen per year was collected. Other abundant species included $A$. decempunctata (13.5\% of all ladybirds), Propylea quatuordecimpunctata (L.) (8.9\%) and Calvia quatuordecimguttata (L.) (5.5\%). Two species, Chilocorus bipustulatus (L.) and Chilocorus renipustulatus (Scriba) were abundant only in 2007, but this was mainly at one site, and their abundance was related to a local outbreak of a scale insect. The total number of aphidophagous ladybirds was highly variable among years, but there was no sign of decline, with the highest number of specimens collected in 2017 (Figure 5).

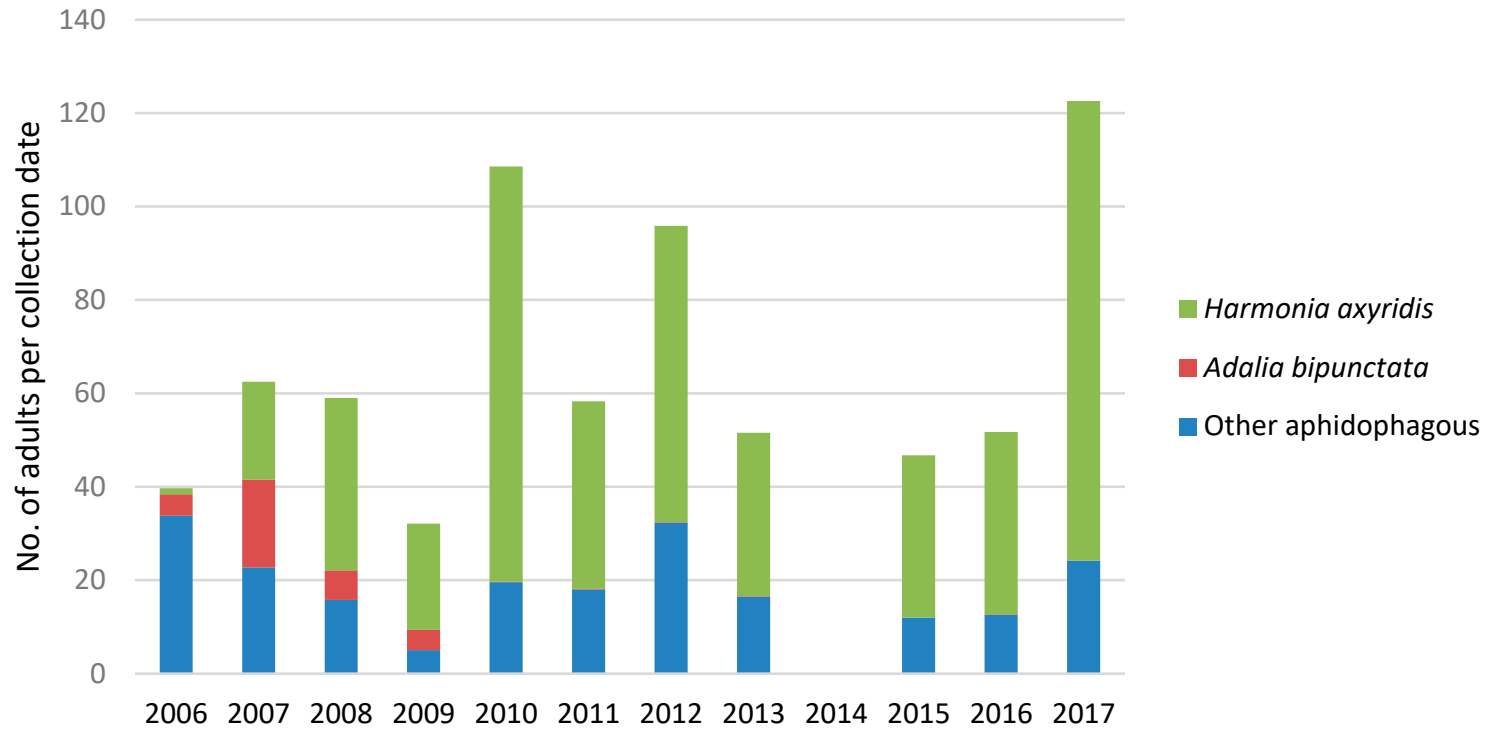

Figure 5. Number of adults of Harmonia axyridis, Adalia bipunctata and other aphidophagous ladybird species collected per collection date on 15 broadleaved hedges from 2006 to 2017.

In meadows, the proportion of $H$. axyridis has remained low since its arrival in Switzerland (Figure 2 and Table 2). Since H. axyridis became abundant in the region in 2008, it represented 3 to $33 \%$ of all ladybirds collected in meadows. Sixteen native species were collected, the three most abundant being Tytthaspis sedecimpunctata (L.) (41.8\%), P. quatuordecimpunctata (26.6\%) and Coccinella septempunctata L. (12.6\%).

On conifers, since the start of the surveys, $H$. axyridis has been more abundant on pine than on spruce. The proportion of $H$. axyridis on pine varied from 0\% in 2009 to 52\% in 2010 (Figure 3 and Table 3). These strong variations are also explained by the low and fluctuating numbers of ladybirds collected on pine (four to 114 individuals per year). Fifteen native species were found on pine and the most abundant species was Harmonia quadripunctata Pontoppidan (26.3\%) followed by H. axyridis $(20.2 \%)$ and C. septempunctata $(16.4 \%)$.

Ladybirds were much more abundant on spruce (100 to 843 individuals per year), but the proportion of $H$. axyridis generally did not exceed $1 \%$ (Figure 4 and Table 4 ). On spruce, the dominant ladybird was by far Aphidecta obliterata (L.) (76.3\%), but 15 native species were collected, including significant numbers of $C$. septempunctata $(13.9 \%)$, which was the most abundant species at one site throughout the period. 


\section{Discussion}

Our long-term survey of ladybirds in north-western Switzerland showed that, on broadleaved trees and shrubs, $H$. axyridis has become by far the most abundant species just a few years after its arrival in Switzerland. Since then, it started to represent between 60 and $80 \%$ of all adult ladybirds. Similar levels of dominance on broadleaved trees were also found recently in other European countries such as England [15], Czech Republic [19] and Italy [20].

Although it is known that ladybird populations can vary greatly from year to year [13] (see also Tables 1-4 for variations observed in some ladybirds, e.g., C. septempunctata and T. sedecimpunctata), the fact that $A$. bipunctata has almost disappeared from our records since 2010 strongly suggests that this decline in populations is not due to natural fluctuations in populations but more probably to the presence of $H$. axyridis. Adalia bipunctata used to be the most abundant species in this habitat in Switzerland [4] and other European countries, e.g., [19-22]. Another 11-year study in England also showed that $A$. bipunctata was the only species to decline significantly after the arrival of $H$. axyridis [15]. Signs of recent decline were also found in other countries such as Czech Republic [19], Italy [20] and Belgium [11]. In the latter country, the decline of $A$. bipunctata warrants red listing as a vulnerable species [23]. Adalia bipunctata, a Holarctic species, is also one of the species that shows the strongest decline in Eastern North America, following the invasion of H. axyridis and three other exotic ladybird species [8]. However, in none of these European and American studies was the decline as strong as in our surveys in north-western Switzerland. For example, in England, A. bipunctata abundance in 2016 was reduced to approximately 16\% of the total from the first surveys in 2006 [15]. Although it has almost disappeared from north-western Switzerland, opportunistic surveys showed that it is still more abundant in other regions, such as in the Valais, southern Switzerland, particularly on deciduous trees in urban settings, perhaps because of the abundance of resources over a long period of the year, which limits intra-guild competition [5].

The decline of $A$. bipunctata following the invasion of $H$. axyridis was expected. The ecological niches of $A$. bipunctata and $H$. axyridis greatly overlap [12,21] and several laboratory studies showed that $A$. bipunctata does not have the same defenses, as other ladybirds to thwart predation by $H$. axyridis e.g., [24-26]. For example, eggs and larvae of C. quatuordecimguttata are chemically protected against IGP by $H$. axyridis, whereas species such as Anatis ocellata (L.) or C. septempunctata have mechanical defense mechanisms. However, three other species (A. decempunctata, C. decemguttata and O. conglobata) also lack defense mechanisms, and have been indicated as potentially at risk in a risk analysis [12]. Yet, they do not seem to decline in north-western Switzerland, at least for now. Adalia decempunctata is now the most abundant native species on broadleaved trees and shrubs. The other two species are less common but still present. In particular, the rare C. decemguttata is regularly monitored on lime trees in the Swiss Jura, and populations do not show any sign of decline [5]. Honek et al. [19] even state that the species is increasing in the Czech Republic despite H. axyridis. The total number of ladybird adults collected in our surveys on broadleaved trees varied quite strongly from year to year, but 2017 was the most successful year in terms of adults collected, suggesting that the biological control function of ladybirds on aphids feeding on broadleaved trees has not been affected by the arrival of H. axyridis. The same conclusion was drawn by Bahlai et al. [13] based on a long-term ladybird survey in Michigan, USA.

Early reports from Belgium and England already showed that $H$. axyridis can become rather abundant on herbaceous plants and conifers [10,21]. In our surveys it never became the dominant species in these habitats, in particular, on spruce, where it was almost absent. A long-term study [15] in England also observed that it was not dominant on pine and nettles, where it represented $11.4 \%$ (fourth most abundant species) and 5.3\% (fifth) of all ladybirds, respectively. These results suggest that it does not represent a significant danger to native ladybirds that are found specifically on conifers and grasses. Nevertheless, the fact that $H$. axyridis represents $20.2 \%$ of all ladybirds on pine in north-western Switzerland prompts us to suggest further studies in this habitat. Furthermore, various studies, mostly from the Americas, showed that it can also become very abundant on annual crops, such as alfalfa fields 
in Chile [9,27] potato fields [28] or across agricultural landscapes [6,8,13] in USA. Thus, their impact on both aphids and aphidophagous insects in such habitats should also be investigated in Europe.

Following this and other studies on the decline of $A$. bipunctata, the following recommendations are made. Firstly, this database of ladybird abundance at 40 sites for 11 years is a unique tool to assess the impact of an invasive insect in the long term. It would be important to sample again at the same sites in a few years to verify that $H$. axyridis remains the dominant species, that the decline of A. bipunctata is confirmed, and that other native lady beetles are not declining. Sampling for at least 3-4 years would be essential to consider the effects of natural fluctuations in ladybird populations.

Secondly, the decline of A. bipunctata should be studied more comprehensively. A national or continental assessment of the situation of $A$. bipunctata would be desirable, since the ladybird does not decline equally everywhere. It would also be necessary to test and analyze, through field observations and laboratory experiments, the factors favoring or hampering the presence of $A$. bipunctata, as well as the mechanisms explaining why this species rather than another is declining. Laboratory studies have already shown that some species of ladybirds such as C. quatuordecimguttata. and C. septempunctata had chemical or physical defenses against $H$. axyridis $[12,26,29]$, but other species, such as $A$. decempunctata, C. decemguttata and $O$. conglobata, also appear vulnerable and, yet, are not affected. It has also been suggested that the decline of native species following the invasion of $H$. axyridis could be due to exploitative or apparent competition through common natural enemies, such as predators, pathogens and parasitoids [30]. This possibility should be further investigated.

Thirdly, the effect of the invasion of $H$. axyridis on aphid populations is still poorly documented in Europe. Unverified information points to a decreasing trend, or at least a status-quo, in aphid-related agricultural problems, which would confirm that the arrival of $H$. axyridis did not alter the natural aphid control function of ladybirds by affecting native ladybird populations. However, it is not excluded that $H$. axyridis has a direct negative effect on native aphid populations, in particular aphids living on deciduous trees. Although it is difficult, long after the invasion of $H$. axyridis, to measure this effect accurately, it is possible that old and long-term data from aphid populations can be compared to new surveys carried out using the same protocols.

\section{Conclusions}

Our long-term monitoring of ladybird populations in north-western Switzerland clearly showed that $H$. axyridis quickly became the dominant species on broadleaved trees and shrubs just a few years after its arrival, but not yet on conifers and grasses. Only one native species, A. bipunctata, clearly declined following the invasion of $H$. axyridis, but this once dominant species almost disappeared from the region. The severe decline of $A$. bipunctata deserves further investigations.

Supplementary Materials: The following are available online at http://www.mdpi.com/2075-4450/11/12/883/s1. Table S1: Characteristics of the ladybird collection sites in the four habitats.

Author Contributions: Conceptualization, M.K. and R.E.; methodology, M.K. and R.E.; investigation, M.K., S.N., J.V.V., R.Z. and R.E.; writing-original draft preparation, M.K.; writing-review and editing, S.N., J.V.V., R.Z. and R.E.; supervision, M.K.; project administration, M.K.; funding acquisition, M.K. All authors have read and agreed to the published version of the manuscript.

Funding: This survey has been mostly funded by grants from the Swiss Federal Office for the Environment, with some additional support from the EU FP6 project ALARM (GOCE-CT-2003-506675).

Acknowledgments: We thank Gian-Reto Walther (Swiss Federal Office for the Environment) for his continuous support. CABI is an international intergovernmental organization, and we gratefully acknowledge the core financial support from our member countries (and lead agencies) including the United Kingdom (Foreign, Commonwealth \& Development Office), China (Chinese Ministry of Agriculture), Australia (Australian Centre for International Agricultural Research), Canada (Agriculture and Agri-Food Canada), Netherlands (Directorate-General for International Cooperation), and Switzerland (Swiss Agency for Development and Cooperation). See https: //www.cabi.org/about-cabi/who-we-work-with/key-donors/ for full details.

Conflicts of Interest: The authors declare no conflict of interest. 


\section{References}

1. Koch, R.L.; Galvan, T.L. Bad side of a good beetle: The North American experience with Harmonia axyridis. Biocontrol 2008, 53, 23-36. [CrossRef]

2. Brown, P.M.J.; Roy, H.E.; Rothery, P.; Roy, D.B.; Ware, R.L.; Majerus, M.E. Harmonia axyridis in Great Britain: Analysis of the spread and distribution of a non-native coccinellid. Biocontrol 2008, 53, 55-67. [CrossRef]

3. Roy, H.E.; Brown, P.M.J.; Adriaens, T.; Berkvens, N.; Borges, I.; Clusella-Trullas, S.; De Clercq, P.; Comont, R.F.; Eschen, R.; Estoup, A.; et al. The harlequin ladybird, Harmonia axyridis: Global perspectives on invasion history and ecology. Biol. Invasions 2016, 18, 997-1044. [CrossRef]

4. Eschen, R.; Babendreier, D.; Nauer, S.; Bigler, F.; Kenis, M. Surveys for ladybirds (Coleoptera: Coccinellidae) in Switzerland and confirmation of the presence of the invasive alien ladybird species, Harmonia axyridis (Pallas). Mitt. Schweiz Entomol. Ges. 2007, 80, 7-14.

5. Kenis, M.; Nacambo, S.; Eschen, R. Suivi de L'impact de la Coccinelle Asiatique Harmonia Axyridis sur les Coccinelles Indigènes; Unpublished Report; CABI: Delémont, Switzerland, 2018.

6. Colunga-Garcia, M.; Gage, S.H. Arrival, establishment, and habitat use of the multicolored Asian lady beetle (Coleoptera: Coccinellidae) in a Michigan landscape. Environ. Entomol. 1998, 27, 1574-1580. [CrossRef]

7. Michaud, J.P. Invasion of the Florida citrus ecosystem by Harmonia axyridis (Coleoptera: Coccinellidae) and asymmetric competition with a native species, Cycloneda sanguinea. Environ. Entomol. 2002, 31, 827-835. [CrossRef]

8. Bahlai, C.A.; Colunga-Garcia, M.; Gage, S.H.; Landis, D.A. The role of exotic ladybeetles in the decline of native ladybeetle populations: Evidence from long-term monitoring. Biol. Invasions 2015, 17, 1005-1024. [CrossRef]

9. Grez, A.A.; Zaviezo, T.; Roy, H.E.; Brown, P.M.; Bizama, G. Rapid spread of Harmonia axyridis in Chile and its effects on local coccinellid biodiversity. Divers. Distrib. 2016, 22, 982-994. [CrossRef]

10. Brown, P.M.J.; Frost, R.; Doberski, J.; Sparks, T.; Harrington, R.; Roy, H.E. Decline in native ladybirds in response to the arrival of Harmonia axyridis: Early evidence from England. Ecol. Entomol. 2011, 36, 231-240. [CrossRef]

11. Roy, H.; Adriaens, T.; Isaac, N.; Kenis, M.; Onkelinx, T.; San Martin, G.; Brown, P.; Hautier, L.; Poland, R.; Roy, D.; et al. Invasive alien predator causes rapid declines of native European ladybirds. Divers. Distrib. 2012, 18, 717-725. [CrossRef]

12. Kenis, M.; Adriaens, T.; Brown, P.M.J.; Katsanis, A.; San Martin, G.; Branquart, E.; Maes, D.; Eschen, R.; Zindel, R.; Van Vlaenderen, J.; et al. Assessing the ecological risk posed by a recently established invasive alien predator: Harmonia axyridis as a case study. Biocontrol 2017, 62,341-354. [CrossRef]

13. Bahlai, C.A.; Colunga-Garcia, M.; Gage, S.H.; Landis, D.A. Long-term functional dynamics of an aphidophagous coccinellid community remain unchanged despite repeated invasions. PLoS ONE 2013,8, e83407. [CrossRef]

14. Lamb, R.J.; Bannerman, J.A.; Costamagna, A.C. Stability of native and exotic lady beetle populations in a diverse landscape. Ecosphere 2019, 10, e02630. [CrossRef]

15. Brown, P.M.J.; Roy, H.E. Native ladybird decline caused by the invasive harlequin ladybird Harmonia axyridis: Evidence from a long-term field study. Insect Conserv. Divers. 2018, 11, 230-239. [CrossRef]

16. Zahradnik, J. Käfer Mittel- und Nordwesteuropas; Paul Parey Verlag: Singhofen, Germany, 1985.

17. Klausnitzer, B.; Klausnitzer, H. Marienkäfer, 4th ed.; Westarp Wissenschaften: Magdeburg, Germany, 1997.

18. Baugnée, J.Y.; Branquart, E. Clef de Terrain Pour la Reconnaissance des Principales Coccinelles de Wallonie (Chilocorinae, Coccinellinae \& Epilachninae); Jeunes et Nature Asbl: Wavre, Belgium, 2000.

19. Honek, A.; Martinkova, Z.; Dixon, A.F.G.; Roy, H.E.; Pekar, S. Long-term changes in communities of native coccinellids: Population fluctuations and the effect of competition from an invasive non-native species. Insect Conserv. Divers. 2016, 9, 202-209. [CrossRef]

20. Masetti, A.; Magagnoli, S.; Lami, F.; Lanzoni, A.; Burgio, G. Long term changes in the communities of native ladybirds in Northern Italy: Impact of the invasive species Harmonia axyridis (Pallas). Biocontrol 2018, 63, 665-675. [CrossRef]

21. Adriaens, T.; Gomez, G.M.Y.; Maes, D. Invasion history, habitat preferences and phenology of the invasive ladybird Harmonia axyridis in Belgium. Biocontrol 2008, 53, 69-88. [CrossRef] 
22. Honek, A.; Martinkova, Z.; Kindlmann, P.; Ameixa, O.M.; Dixon, A.F. Long-term trends in the composition of aphidophagous coccinellid communities in central Europe. Insect Conserv. Divers. 2014, 7, 55-63. [CrossRef]

23. Adriaens, T.; San Martin y Gomez, G.; Bogaert, J.; Crevecoeur, L.; Beuckx, J.-P.; Maes, D. Testing the applicability of regional IUCN Red List criteria on ladybirds (Coleoptera, Coccinellidae) in Flanders (north Belgium): Opportunities for Conservation. Insect Conserv. Divers. 2015, 8, 404-417. [CrossRef]

24. Ware, R.L.; Majerus, M.E.N. Intraguild predation of immature stages of British and Japanese coccinellids by the invasive ladybird Harmonia axyridis. Biocontrol 2008, 53, 169-188. [CrossRef]

25. Ware, R.L.; Evans, N.; O'Farrell, K.; Majerus, M.E.N.; Malpas, L.; Michie, L.J. Intraguild predation of British and Japanese coccinellid eggs by the invasive ladybird Harmonia axyridis. Neobiota 2008, 7, 263-275.

26. Katsanis, A.; Babendreier, D.; Nentwig, W.; Kenis, M. Intraguild predation between the invasive ladybird Harmonia axyridis and non-target European coccinellid species. Biocontrol 2013, 58, 73-83. [CrossRef]

27. Grez, A.A.; Zaviezo, T.; Hernández, J.; Rodríguez-San Pedro, A.; Acuña, P. The heterogeneity and composition of agricultural landscapes influence native and exotic coccinellids in alfalfa fields. Agric. For. Entomol. 2014, 16, 382-390. [CrossRef]

28. Alyokhin, A.; Sewell, G. Changes in a lady beetle community following the establishment of three alien species. Biol. Invasions 2004, 6, 463-471. [CrossRef]

29. Katsanis, A.; Magro, A.; Ramon-Portugal, F.; Kenis, M.; Babendreier, D. Chemical defences of native European coccinellid eggs against intraguild predation by the invasive Asian coccinellid, Harmonia axyridis (Pallas). Biocontrol 2017, 62, 385-396. [CrossRef]

30. Smith, C.A.; Gardiner, M.M. Biodiversity loss following the introduction of exotic competitors: Does intraguild predation explain the decline of native lady beetles? PLoS ONE 2013, 8, e84448. [CrossRef] [PubMed]

Publisher's Note: MDPI stays neutral with regard to jurisdictional claims in published maps and institutional affiliations. 